\title{
Sigmoid volvulus causing displacement of the liver and gastric outlet obstruction
}

Siun M Walsh, John O Larkin
Department of Surgery, St James Hospital, Dublin, Ireland

Correspondence to Siun M Walsh, siunwalsh@gmail.com

Accepted 2 July 2015
To cite: Walsh SM, Larkin JO. BMJ Case Rep Published online: [please include Day Month Year] doi:10.1136/bcr-2015210317

\section{DESCRIPTION}

A 50-year-old man with no significant medical history presented with a 2-day history of severe abdominal pain, vomiting and complete constipation. Physical examination revealed a distended, tympanitic abdomen with mild tenderness in the right upper quadrant. Serum lactate was $4.8 \mathrm{mmol} / \mathrm{L}$ (normal $0.5-2.2 \mathrm{mmol} / \mathrm{L}$ ). Abdominal X-ray showed a distended stomach. CT of the abdomen showed a grossly distended sigmoid volvulus (blue arrow) with swirling of the mesentery (green arrow; figure 1), proximal large bowel obstruction (white arrow), medial displacement of the liver (red block arrow) and gastric outlet obstruction (red arrow; figure 2). At emergency laparotomy, a gangrenous sigmoid volvulus was found and resection with primary anastomosis was carried out. The patient made an uneventful recovery and was discharged home well on postoperative day 8 .
To the best of our knowledge, there are no previous reports of sigmoid volvulus causing liver displacement or gastric outlet obstruction.

\section{Learning points}

Sigmoid volvulus may cause displacement of the liver.

- Gastric outlet obstruction is a rare presentation of sigmoid volvulus.

\section{Competing interests None declared.}

Patient consent Obtained.

Provenance and peer review Not commissioned; externally peer reviewed.

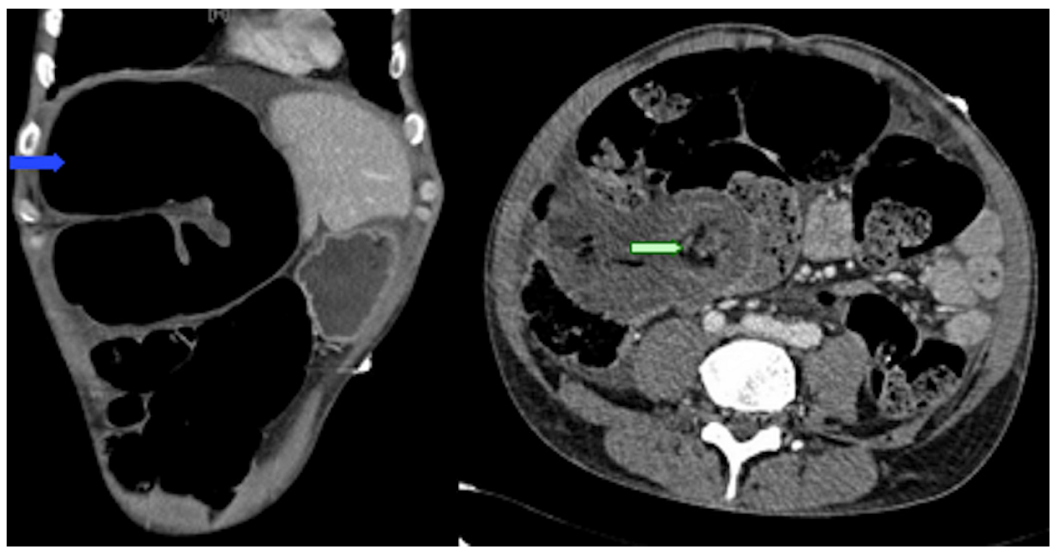

Figure 1 CT of the abdomen showed a grossly distended sigmoid volvulus (blue arrow) with swirling of the mesentery (green arrow).

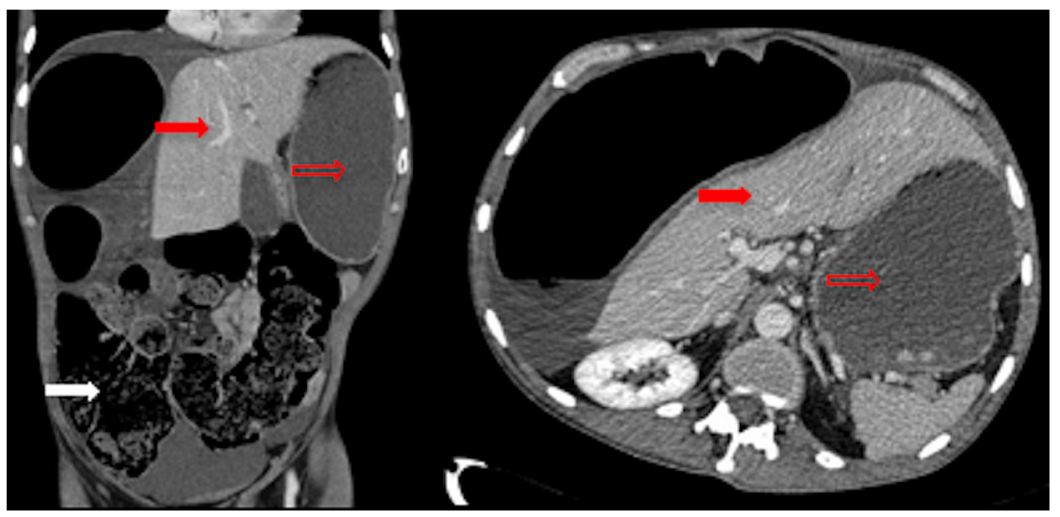

Figure 2 CT of the abdomen showing proximal large bowel obstruction (white arrow), medial displacement of the liver (red block arrow) and gastric outlet obstruction (red arrow). 


\section{Images in...}

Copyright 2015 BMJ Publishing Group. All rights reserved. For permission to reuse any of this content visit http://group.bmj.com/group/rights-licensing/permissions.

BMJ Case Report Fellows may re-use this article for personal use and teaching without any further permission.

Become a Fellow of BMJ Case Reports today and you can:

- Submit as many cases as you like

- Enjoy fast sympathetic peer review and rapid publication of accepted articles

- Access all the published articles

- Re-use any of the published material for personal use and teaching without further permission

For information on Institutional Fellowships contact consortiasales@bmjgroup.com

Visit casereports.bmj.com for more articles like this and to become a Fellow 